\title{
ОТНОШЕНИЕ ОБЩЕСТВА К ДЕТЯМ С ПРОБЛЕМАМИ В РАЗВИТИИ
}

\section{SOCIETY ATTITUDE TO CHILDREN WITH DEVELOPMENTAL PROBLEMS}

M. Arbuzova

Summary: The focusing of attention of modern society on the developing model of society's attitude towards children with developmental problems is considered by the author as one of the most effective factors of socialization and integration of a child into age-appropriate types and forms of social life. The article analyzes the current problems of society's attitude towards children with developmental problems, identifies and describes the prospects for their solution, determines the importance of psychological support for the education of children with developmental problems.

Keywords: society, children with developmental problems, defectology, special psychology, ethics, socialization.

\author{
Арбузова Мария Георгиевна \\ РГПУ им. А.И. Гериена \\ mariarbuzovax@yandex.ru
}

Аннотация: Акцентирование внимания современного социума на развивающей модели отношения общества к детям с проблемами в развитии рассматривается автором как один из наиболее эффективных факторов социализации и интеграции ребенка в соответствующие возрасту виды и формы социальной жизни. В статье проанализированы актуальные проблемы отношения общества к детям с проблемами в развитии, выявлены и охарактеризованы перспективы их решения, определена значимость психологического сопровождения образования детей с проблемами в развитии.

Ключевые слова: общество, дети с проблемами в развитии, дефектология, специальная психология, этика, социализация.
$\mathrm{O}$ тношение к детям с проблемами в развитии видоизменялось вместе с формированием и развитием человеческой цивилизации. Инфантицид считался приемлемым, например, в эпоху Античности. Родители избавлялись от ребенка в случаях, когда нарушения развития были заметны сразу. Таким образом, прежде всего, умерщвлялись дети с физическими недостатками, так как психологические, при их наличии, еще не могли быть проявлены. Общество не поощряло убийство уже после признания ребенка отцом. Только при последнем из династии Северов римском императоре Александре Севере такая традиция как выбрасывание ребенка стала приравниваться к убийству. Следует отметить, что социализация ребенка с нарушениями в развитии была вполне возможна при условии достаточной обеспеченности семьи, в которой он родился. В качестве объяснения инфантицида можно привести такие факторы как древнегреческая модель представления о гармоничной структуре мира, о богах как эталонах, к которым физически и душевно должен быть стремиться человек, представления древних римлян о значимости воина (соответственно обладающего набором отличных физических и волевых качеств) и т.д. Для Римской империи настоль важна была гражданственность, что инвалиды, как неспособные принимать участие в деятельном развитии Римской империи (с точки зрения древних римлян), причислялись к негражданам.

В обществе проблема инфантицида, проблема оставления ребенка на произвол судьбы (еще одна античная традиция) не считалась значимой, не изучалась и не обсуждалась вплоть до начала распространения христианства. Тем не менее и в Средние века отношение к детям с проблемами в развитии не было однозначным. В славянских странах формируется особое отношение к восприятию людей с нарушениями в развитии как юродивых и блаженных. Наряду с проявлением любви, заботы, милосердия сохраняется традиция дискриминации, растет число суеверий и предубеждений все на том же основании - человек не подобен Богу, это кара за совершенные злодеяния.

Иная философско-культурологическая модель мира прослеживается в эпоху Возрождения. Антропоцентризм способствует восприятию каждого человека обществом как свободной личности, равной другим, имеющей неограниченные возможности. Нарушения развития перестают вызывать страх, так как начинают изучаться. C XIV века начинают разрабатываться индивидуальные программы обучения для детей с проблемами развития (речь идет о детях высших сословий).

Формирование капиталистических отношений Нового времени способствовало прагматическому взгляду общества - если человек, не смотря на нарушения в развитии, способен трудиться, то общество воспринимало его как позитивный социальный элемент, если физическое или психическое состояние не позволяло ему работать, то он воспринимался негативно, только как потребитель. Это в первую очередь относилось к бедным 


\section{слоям населения.}

Формирование новых научных и философских теорий в XX веке способствовало не только изменению отношения к детям с нарушениями в развитии, но и созданию ряда учреждений для детей-инвалидов. Тем не менее зародившаяся в конце XIX века евгеника стала популярной в начале XX века и пропагандировалась в нацисткой Германии. Таким образом, на протяжении различных культурно-исторических эпох общество использовало различные модели отношения к детям с нарушениями в развитии. Негативное отношение при этом, на протяжении всей истории цивилизации, нивелировалось состоятельностью и положением семьи, в которой родился ребенок.

Можно определить следующие модели отношения общества к детям с проблемами в развитии: негуманное отношение общества к «недочеловеку» (восприятие человека с проблемами в развитии как неполноценного существа); ограждение от «угрозы» обществу (создание закрытых учреждений, зачастую со строгим режимом и недостаточным образовательным компонентом или его отсутствием); проявление излишней заботы и жалости, отношение «как к ребенку» сохраняется и во взрослом возрасте (вместо обеспечения надлежащей помощи в развитии и образовании создается комфортной среда обитания, мир за пределами которой представляется враждебным и опасным для всех сторон); общество оказывает помощь, но воспринимает ее как обременение, постоянно пытаясь сократить экономические расходы; восприятие детей с проблемами в развитии как «больных людей» (имеет двойственный эффект одновременно стимулирует развитие медицины и науки, способствует профилактике и лечению причин и последствий проблем развития, но в современных реалиях считается недостаточной, поскольку сама по себя является ограничителем возможностей людей с особыми потребностями); развивающая модель, при которой общество берет на себя ответственность за более полное развитие детей с проблемами в развитии, признает наличие у них способностей и возможностей к развитию и образованию.

Таким образом, наиболее гуманной и прогрессивной моделью можно считать развивающую модель отношения общества к детям с проблемами в развитии. Главной целью такой модели должна стать социализация индивида, будущего взрослого, полноправного члена общества. Первостепенными задачами на начальном этапе соответственно будут являться: создание условий, компенсирующих отклонения в развитии и ограничения возможностей; интеграция ребенка в соответствующие возрасту виды и формы социальной жизни, прежде всего, при участии специалиста дефектолога, осуществляющего психологическое сопровождение в образовательную среду, которая может дать наибольшей спектр возможностей в дальнейшем. Вопросы, связанные с образованием детей, имеющих проблемы в развитии, стоят сегодня наиболее остро, они находятся в поле зрения современного научного сообщества. Внимание уделяется отдельным аспектам образовательной интеграции детей с ограниченными возможностями [3], сосредотачивается на проблеме формирования социального опыта у младших школьников с умеренной умственной отсталостью [6] и т.д. В более широком рассмотрении заявленной в теме статьи проблемы значимыми представляются исследование стереотипов о людях с ограниченными возможностями здоровья [2] и исследование понимания человеком окружающего мира в условиях социально созданной полифункциональной интерактивной среды [4]. Выбор формы обучения в коррекционном (специализированном) или общеобразовательном учебном заведении должен определяться индивидуализировано. Вопрос об инклюзивном образовании стоит в настоящее время достаточно остро, является предметом дискуссии среди специалистов в области образования, коррекционной психологии, а также родителей. «Дело в том, что невозможно себе представить, чтобы в условиях сегодняшнего существования школы и образования в целом, нормально развивающиеся дети смогли в условиях инклюзии достигать максимально высокой планки своих образовательных возможностей. Интеграционно-инклюзивная форма обучения может быть эффективной только при условии максимальной дифференциации образовательных услуг по адресу каждого ребенка. Сегодня даже намека нет на качество таких услуг. Только будучи неуемным оптимистом можно признать, что успешная дифференциация образовательных услуг может быть достигнута менее чем за полвека (и это в случае, если не будет экономических и политических катаклизмов и если мы неотступно будем заниматься совершенствованием инклюзивной формы обучения)» [7;58]. Ещё одной важной задачей, обеспечивающей полноценное функционирование механизмов работы такой модели, представляется психокоррекционная работа с самим ребенком и его родителями. В родителях необходимо сформировать осознание значимости понятия «безусловная родительская любовь», оказать помощь в понимании важности поисков задатков и одаренностей у ребенка. «Главная задача всех лиц, работающих с ребенком, состоит в том, чтобы обеспечить положительные изменения в развитии его как личности. Но для этого необходимы не разовые и не односторонние меры, а комплексный, системный подход, предполагающий учет как внешних, так и внутренних факторов, воздействующих на личность. Вот почему деятельность специалиста по социальной реабилитации детей с ограниченными возможностями здоровья должна быть многоплановой и включать в себя все основные направления социально-реабилитационного процесса.

Такими направлениями, на наш взгляд, являются: ор- 
ганизаторская деятельность; деятельность по диагностике психического и личностного развития ребенка; развивающая и коррекционная работа; консультирование и просвещение детей, родителей и специалистов, занимающихся с детьми; деятельность по охране здоровья и безопасной жизнедеятельности и социально-диспетчерская работа»[1;59-60].

Социализация детей с проблемами в развитии предполагает, что в процессе обучения будет оказана помощь и в выборе будущей профессии. «Неоценимую помощь в профессиональном самоопределении для детей с ограниченными возможностями здоровья может оказать система дополнительного образования» [5;25]. Дополнительное образование способно расширить спектр выбора направлений будущей профессиональной деятельности, разнообразить учебный процесс, помочь найти единомышленников, дать более конкретные и глубокие знания по интересующим ребенка или подростка направлениям.

Современное общество, ориентированное на ценно- сти гуманизма, ставит заявленную в названии проблему достаточно остро. Развивающаяся в настоящее время генотерапия - это тоже запрос общества. Направление имеет неоднозначную трактовку, это сравнительно новое направление и пока более явны его положительные стороны, успехи, нежели риски, которые могут проявиться позже, например, через поколение. Но этот запрос также может не только оградить ребенка от страданий, но и «очистить», выхолостить общество, довести его до совершенства, таким образом, сняв с себя ответственность за содержание, необходимость помощи, необходимости внутреннего духовного роста личности в процессе общения с детьми с нарушениями в развитии и т.д.

В современном обществе назрела необходимость поиска этических констант в отношении к детям с проблемами в развитии. Вопрос не только в отношении общества, но в осознании того, что эти дети и эти личности - тоже полноценные члены общества, и их отношение к нам должно нас заботить не меньше, чем наше к ним.

\section{ЛИТЕРАТУРА}

1. Акатов, Л.И. Социальная реабилитация детей с ограниченными возможностями здоровья. Психологические основы. / Л.И. Акатов. - М.: Владос, 2003. 368 c.

2. Богачек, И.С. Исследование стереотипов о людях с ограниченными возможностями здоровья / И.С. Богачек, А.А. Куланова, М.А. Гритчина // Специальное и инклюзивное образование: Методология, теория, практика: сборник научно-методических трудов с международным участием / РГПу. - СанктПетербург, 2016. - С. 139-140.

3. Богачек, И.С. Некоторые аспекты образовательной интеграции детей с ограниченными возможностями / И.С. Богачек // Духовно-нравственные ориентиры специального образования: материалы XVII Междунар. конф. «Ребенок в современном мире. Духовные горизонты детства», 21-23 апр. 2010 г. - СПб., 2010. - С. 103-106.

4. Богачек, И. С. Понимание человеком окружающего мира в условиях социально созданной полифункциональной интерактивной среды / И.С. Богачек // Образовательная интеграция детей с особыми потребностями: социокультурные стратегии и перспективы: материалы XVI Междунар. конф. «Ребенок в современном мире. Детство и социокультурная прогностика», $22-24$ апр. 2009 г. - СПб., 2009. - С. 362-366

5. Васильченко, А.Е. Особенности социализации детей с ограниченными возможностями здоровья / А.Е. Васильченко, 0. В. Кузнецова // Наука и социум. Материалы Всероссийской научно-практической конференции с международным участием (15 декабря 2018 г.). - Новосибирск: Изд-во АНО ДПО «СИППСР», 2018. - С.22-26

6. Зарин, А. К проблеме формирования социального опыта у младших школьников с умеренной умственной отсталостью / А. Зарин, С.А. Мухтарова // Традиции и инновации в специальном образовании. Материалы XIV Международной конференции «Ребенок в современном мире. Образование и детство» (12-18 апреля 2007 г.) ЮНЕСКО, Министерство образования и науки РФ, Российский государственный педагогический университет им. А.И. Герцена, Северо-Западное отделение РАО, Ком.по образованию и науке Гос. Думы РФ, Ком. по науке и высш. шк. администрации Санкт-Петербурга, С.-Петерб. акад. детства, Петров. акад. наук и искусств, факультет философии человека РГПУ им. А. И. Герцена, Герценовское филос. об-в0.- СПб.: , 2007. - С. $342-344$.

7. Матасов, Ю.Т. Философские и нравственные аспекты интеграции и инклюзивного обучения/ Ю.Т. Матасов // Вестник Герценовского университета. - РГПу. - СПБ, 2012. - № 2. - С.56-59

() Арбузова Мария Георгиевна (mariarbuzovax@yandex.ru).

Журнал «Современная наука: актуальные проблемы теории и практики» 